\title{
Sesquiterpene Lactones, Acyl Phenyl Propanoids and Other Constituents from Schkuhria pinnata var. wislizeni. Antioxidant Evaluation
}

\author{
Alejandra León, Blanca M. Reyes, María Isabel Chávez, Rubén A. Toscano, and Guillermo Delgado* \\ Instituto de Química de la Universidad Nacional Autónoma de México. Circuito Exterior, Ciudad Universitaria. Coyoacán 04510. \\ México, D. F. delgado@unam.mx \\ Dedicated to the memory of Prof. Ernest L. Eliel
}

Received August 5, 2009; Accepted September 25, 2009

\begin{abstract}
Chemical investigation of aerial parts of Schkuhria pinnata var wislizeni (Asteraceae) allowed the characterization of the sesquiterpene lactones $\mathbf{1 , 2}$ and $\mathbf{5}$, the flavonoids $\mathbf{3}$ and $\mathbf{4}$, and the acyl phenyl propanoids $\mathbf{1 0}$ and 11. Structure 2, named dischkuhriolin, was confirmed as a Diels Alder adduct of $\mathbf{1}$ as dienophile and a guaianolide as diene. Spectroscopic analysis of $\mathbf{5}$ and its diacetyl derivative allowed the structural correction of compounds previously reported from Schkuhria. 2, 10 and $\mathbf{1 1}$ are new natural compounds. Biological assays indicated that the mixture $\mathbf{1 0}+\mathbf{1 1}$ showed antioxidant activity expressed as inhibition of AAPH-induced damage in rat pancreatic homogenate.

Key words: Asteraceae, Schkuhria pinnata var. wislizeni, 11,13dehydroeriolin, dischkuhriolin, 14-O-schkuhridin B, flavonoids, acyl phenyl propanes, antioxidant activity.
\end{abstract}

The genus Schkuhria (Asteraceae, tribe Heliantheae) is a relatively small genus taxonomically related to the genus Bahia located mainly in America and some specimens are reported from Africa, where they probably were introduced [1]. The botanical characteristics of Schkuhria have been discussed $[2,3]$ and recently, S. pinnata was treated as having two varieties [4], although perhaps some confirmations are needed [5]. Some Schkuhria species are used in traditional medicine $[1,6,7]$ and S. pinnata has ethnoveterinary use [8]. Chemical investigations from this genus have afforded polyacetylenes [9], diterpenes [10], sesquiterpene lactones [11,12,13,14], phenylpropanoids [15] and some of these constituents displayed different biological activities [16].

As part of our investigations aimed at the characterization of biologically active compounds from the Mexican flora [17], we have undertaken the chemical study of Schkuhria pinnata var wislizeni, a bush distributed in South western and South central United States, Northern and Central Mexico and Mesoamerica [18]. According the botanical reclassification for Schkuhria, $S$. virgata, $S$. anthemoidea and other species and their varieties have been recognized as a single species and renamed as S. pinnata var. wislizeni [4]. In a previous investigation we characterized 11,13-dehydroeriolin (1) as the major constituent from what was named at that time as S. virgata [19]. Due to the traditional use of this species [6] we reinvestigated this plant with the aim of looking for additional metabolites and evaluate their anti-oxidant potential.

The aerial parts of S. pinnata var. wislizeni, collected in the State of Guanajuato (Central Mexico) during blossom in
Resumen. La investigación química de las partes aéreas de Schkuhria pinnata var wislizeni (Asteraceae) permitió la caracterización de las lactonas sesquiterpénicas $\mathbf{1}, 2$ y $\mathbf{5}$, los favonoides 3 y $\mathbf{4}$, y los acil fenil propanoides $\mathbf{1 0}$ y $\mathbf{1 1}$. La estructura $\mathbf{2}$, nombrada como dieschkuhriolina, fue confirmada como un aducto de Diels Alder de $\mathbf{1}$ como dienófilo y una guayanólida como dieno. El análisis epectroscópico de 5 permitió la corrección estructural de compuestos reportados previamente de Schkuhria. 2, 10 y 11 son nuevos compuestos naturales. Los ensayos biológicos indicaron que la mezcla $\mathbf{1 0}+\mathbf{1 1}$ mostró actividad antioxidante expresada como inhibición del daño inducido por HAAP en homogenado pancreático de rata.

Palabras clave: Asteraceae, Schkuhria pinnata var. wislizeni, 11,13dehidroeriolina, dieschkuhriolina, 14-O-skuhridina B, flavonoides, acil fenil propanos, actividad antioxidante.

2001, were dried and sequentially extracted with $n$-hexane and acetone. The acetone extract was subjected to vacuum liquid chromatography (VLC) over a column packed with silica gel, affording a series of fractions, which were further purified to afford compounds $\mathbf{1 - 5}, \mathbf{1 0}, \mathbf{1 1}$. The structures of 11,13-dehydroeriolin (1) [19, 20], pectolarigenin (3) [21], hispidulin (4) [22] and p-hydroxy-benzaldehyde [23] were determined by comparison of their spectroscopic data with those reported in the literature. Spectroscopic discussion of 5 and its diacetyl derivative $\mathbf{6}$ allowed the structural correction of the sesquiterpene lactones $\mathbf{8}$ and $\mathbf{9}$ previously isolated from S. anthemoidea var. wislizeni [24]. Compounds 2, 10 and $\mathbf{1 1}$ are new.
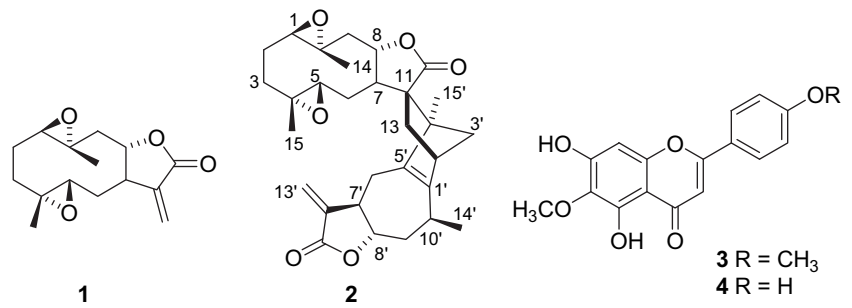

1

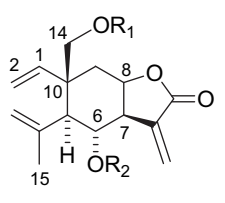

$5 \mathrm{R}_{1}=\mathrm{Ac}, \mathrm{R}_{2}=\mathrm{H}$ $6 R_{1}=A c, R_{2}=A c$ $7 \mathrm{R}_{1}=\mathrm{H}, \quad \mathrm{R}_{2}=\mathrm{H}$

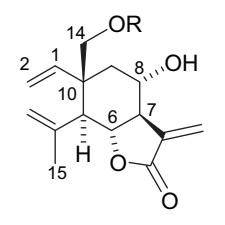
$\begin{array}{ll}8 & R=A c \\ 9 & R=H\end{array}$ 


\section{Results and Discussion}

The molecular formula $\mathrm{C}_{30} \mathrm{H}_{38} \mathrm{O}_{6}$, defining twelve unsaturation degrees, was assigned to compound 2 by HRMS. Its IR spectrum displayed a strong absorption at $1760 \mathrm{~cm}^{-1}$, indicating the presence of at least one $\gamma$-lactone. Analysis of ${ }^{1} \mathrm{H}$ and ${ }^{13} \mathrm{C}$ NMR data of $2\left(\mathrm{CDCl}_{3}\right.$, Table 1$)$, assisted by $2 \mathrm{D}$ HMBC, COSY and NOESY experiments, indicated the presence of two carbonyls $\left(\delta_{\mathrm{C}} 179.82\right.$ and 169.76), two double bonds, one tetrasubstituted $\left(\delta_{\mathrm{C}} 151.22,136.85\right)$ and the other one geminally disubstituted $\left(\delta_{\mathrm{C}} 119.17, \delta_{\mathrm{H}} 5.55, \mathrm{~d}, J=3.5\right.$, and 6.22 , d, $\left.J=3.5 ; \delta_{\mathrm{C}} 139.71\right)$, four oxymethines $\left(\delta_{\mathrm{C}} 65.25,64.57,81.03\right.$ and $80.72 ; \delta_{\mathrm{H}} 2.81 ; 2.54,4.01$ and 4.21 , respectively), two quaternary $\mathrm{sp}^{3}$ carbons linked to oxygen $\left(\delta_{\mathrm{C}} 57.75,60.80\right)$, and two quaternary sp ${ }^{3}$ carbons $\left(\delta_{\mathrm{C}} 55.25,62.42\right)$. The remaining sixteen carbons were assigned to four methyls, eight $\mathrm{sp}^{3}$

Table 1. ${ }^{1} \mathrm{H}$ and ${ }^{13} \mathrm{C}$ NMR spectral data of compound $2\left({ }^{\mathrm{a}} \mathrm{CDCl}_{3}, 500 \mathrm{MHz} ;{ }^{\mathrm{b}} \mathrm{CDCl}_{3}, 125 \mathrm{MHz}\right)$.

\begin{tabular}{|c|c|c|c|c|c|}
\hline Position & $\delta_{\mathrm{H}}(J \text { in } \mathrm{Hz})^{\mathrm{a}}$ & $\delta_{\mathrm{C}}^{\mathrm{b}}$ & ${ }^{1} \mathrm{H}^{-1} \mathrm{H} \mathrm{COSY}$ & ${ }^{1} \mathrm{H}-{ }^{13} \mathrm{C}$ HMBC & ${ }^{1} \mathrm{H}-{ }^{1} \mathrm{H}$ NOESY \\
\hline $1 \alpha$ & $2.81 \mathrm{dd}(9.0,1.0)$ & 65.25 & $\mathrm{H}-2 \alpha, \mathrm{H}-2 \beta$ & $\mathrm{C}-2\left(J^{2}\right), \mathrm{C}-10\left(J^{2}\right)$ & $\mathrm{H}-5 \alpha, \mathrm{H}-7 \alpha$ \\
\hline $2 \alpha$ & $2.14 \mathrm{bd}$ & 23.91 & $H-1 \alpha, H-3 \alpha, H-3 \beta$ & $\mathrm{C} 10\left(J^{3}\right)$ & $\mathrm{H}-3 \beta$ \\
\hline $2 \beta$ & $1.43 \mathrm{~m}$ & & & & $\mathrm{H}-14 \beta$ \\
\hline $3 \alpha$ & $1.24 \mathrm{~m}$ & 35.45 & $\mathrm{H}-2 \alpha, \mathrm{H}-2 \beta$ & $\mathrm{C}-1\left(\mathcal{J}^{3}\right)$ & $H-5 \alpha$ \\
\hline $3 \beta$ & $2.21 \mathrm{ddd}(14.5,3.5,3.5)$ & & & & $\mathrm{H}-2 \alpha$ \\
\hline 4 & & 60.80 & & & \\
\hline $5 \alpha$ & $2.54 \mathrm{~d}(10.0)$ & 64.57 & H- $6 \alpha, H-6 \beta$ & $\mathrm{C}-6\left(J^{2}\right), \mathrm{C}-7\left(J^{3}\right)$ & 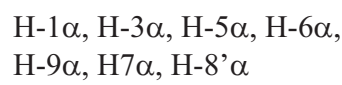 \\
\hline $6 \alpha$ & $1.28 \mathrm{ddd}(15.0,10.0,10.0)$ & 29.63 & $\mathrm{H}-5 \alpha, \mathrm{H}-7 \alpha$ & $\mathrm{C}-5\left(J^{2}\right), \mathrm{C}-4\left(J^{3}\right)$ & $\mathrm{H}-5 \alpha$ \\
\hline $6 \beta$ & $1.80 \mathrm{~d}(15.0)$ & & & $\mathrm{C}-11\left(\mathcal{J}^{3}\right)$ & $\mathrm{H}-15 \beta$ \\
\hline $7 \alpha$ & $2.02 \mathrm{dd}(10.0,10.0)$ & 46.77 & H- $6 \alpha, \mathrm{H}-6 \beta, \mathrm{H}-8 \beta$ & $\begin{array}{l}\mathrm{C}-11\left(J^{2}\right), \mathrm{C}-13\left(J^{3}\right), \mathrm{C}-4^{\prime}\left(J^{3}\right), \\
\mathrm{C}-9\left(J^{3}\right), \mathrm{C}-5\left(J^{3}\right)\end{array}$ & $\mathrm{H}-5 \alpha$ \\
\hline $8 \beta$ & $4.01 \mathrm{ddd}(10.0,10.0,1.5)$ & 81.03 & H-7 $\alpha, \mathrm{H}-9 \alpha, \mathrm{H}-9 \beta$ & $\mathrm{C}-6\left(J^{3}\right)$ & H-9 $9, \mathrm{H}-14 \beta$ \\
\hline $9 \alpha$ & $1.44 \mathrm{dd}(14.0,10.0)$ & 45.50 & $\mathrm{H}-8 \beta$ & $\mathrm{C}-14\left(J^{3}\right)$ & $\mathrm{H}-5 \alpha$ \\
\hline $9 \beta$ & $2.80 \mathrm{dd}(14.0,1.5)$ & & & $\mathrm{C}-10\left(J^{2}\right)$ & $\mathrm{H}-8 \beta, \mathrm{H}-14$ \\
\hline 10 & & 57.75 & & & \\
\hline 11 & & 55.25 & & & \\
\hline 12 & & 179.82 & $\mathrm{H}-13 \alpha, \mathrm{H}-13 \beta$ & & \\
\hline $13 \mathrm{a}$ & $1.74 \mathrm{dd}(12.5,3.0)$ & 36.92 & $\mathrm{H}-2^{\prime} \alpha$ & $\mathrm{C}-12\left(J^{3}\right), \mathrm{C}-3^{\prime}\left(\mathcal{J}^{3}\right)$ & $\mathrm{H} 13 \mathrm{~b}$ \\
\hline $13 b$ & $2.06 \mathrm{dd}(12.5,3.0)$ & & & $\mathrm{C}-1^{\prime}\left(J^{3}\right), \mathrm{C}-2^{\prime}\left(J^{2}\right)$ & $\mathrm{H} 2^{\prime} \alpha, \mathrm{H}-3^{\prime} \beta, \mathrm{H}-13 \alpha$ \\
\hline $14 \beta$ & $1.37 \mathrm{~s}$ & 18.07 & & $\mathrm{C}-10\left(J^{2}\right), \mathrm{C}-9\left(J^{\mathcal{3}}\right), \mathrm{C}-1\left(J^{\mathcal{3}}\right)$ & H- $2 \beta, H-8 \beta, H-9 \beta, H 15 \beta$ \\
\hline $15 \beta$ & $1.21 \mathrm{~s}$ & 16.41 & & $\mathrm{C}-4\left(J^{2}\right), \mathrm{C}-3\left(J^{3}\right), \mathrm{C}-5\left(J^{3}\right)$ & $\mathrm{H}-6 \beta, \mathrm{H}-14 \beta, \mathrm{H}-8 \beta$ \\
\hline 1 ' & & 151.22 & & & \\
\hline $2^{\prime} \alpha$ & $2.66 \mathrm{~m}$ & 48.36 & $H-3^{\prime} \alpha, H-3^{\prime} \beta$ & $\mathrm{C}-4^{\prime}\left(J^{3}\right)$ & $\mathrm{H}-3^{\prime} \alpha, \mathrm{H}-10 \alpha, \mathrm{H}-13 \beta$ \\
\hline $3^{\prime} \alpha$ & $1.28 \mathrm{~m}$ & 52.18 & $\mathrm{H}-2^{\prime} \alpha$ & $\mathrm{C}-13\left(J^{3}\right), \mathrm{C}-4^{\prime}\left(J^{2}\right)$ & $H-2^{\prime} \alpha, H-3^{\prime} \beta$ \\
\hline $3^{\prime} \beta$ & $2.46 \mathrm{~d}(8.5)$ & & & $\mathrm{C}-5^{\prime}\left(J^{2}\right), \mathrm{C}-1^{\prime}\left(J^{\prime}\right)$ & $H-3^{\prime} \beta, H-13 b, H-15 \alpha$ \\
\hline 4, & & 62.42 & & & \\
\hline 5 , & & 136.85 & & & \\
\hline $6^{\prime} \alpha$ & $2.81 \mathrm{dd}(15.0,3.5)$ & 26.74 & H-7' $\alpha$ & $\mathrm{C}-7^{\prime}\left(J^{2}\right), \mathrm{C}-4^{\prime}\left(J^{2}\right)$ & $H-7^{\prime} \alpha$ \\
\hline $6^{\prime} \beta$ & $1.72 \mathrm{dd}(15.0,10.5)$ & & & $\mathrm{C}-1^{\prime}\left(J^{\mathcal{3}}\right), \mathrm{C}-5^{\prime}\left(J^{2}\right)$ & $\mathrm{H}-8 \beta$ \\
\hline $7^{\prime} \alpha$ & $\begin{array}{l}2.59 \text { ddddd }(10.5,9.5,3.5 \\
3.5,3.5)\end{array}$ & 47.72 & H-6' $\alpha, H-6^{\prime} \beta$ & & $\mathrm{H}-6^{\prime} \alpha$ \\
\hline $8^{\prime} \beta$ & $4.21 \mathrm{ddd}(12.0,9.5,2.0)$ & 80.72 & $\mathrm{H}-7^{\prime} \alpha, \mathrm{H}-9^{\prime} \alpha, \mathrm{H}-9^{\prime} \beta$ & $\mathrm{C}-6^{\prime}\left(J^{3}\right)$ & H- $6 \beta, H-9{ }^{\prime} \beta, H-5 \alpha$ \\
\hline $9^{\prime} \alpha$ & $1.97 \mathrm{ddd}(13.0,12.0,5.5)$ & 39.72 & & $\mathrm{C}-10^{\prime}\left(J^{2}\right), \mathrm{C}-1^{\prime}\left(J^{3}\right)$ & $\mathrm{H}-9^{\prime} \beta, \mathrm{H}-10^{\prime} \alpha$ \\
\hline $9^{\prime} \beta$ & 2.23 ddd $(13.0,12.0,2.0)$ & & & & $\mathrm{H}-8^{\prime} \beta$ \\
\hline $10^{\prime} \alpha$ & $2.96 \mathrm{ddq}(5.5,2.0)$ & 32.68 & $H-9^{\prime} \alpha, H-9{ }^{\prime} \beta, H-14^{\prime} \beta$ & $\mathrm{C}-14^{\prime}\left(J^{2}\right)$ & $H-2^{\prime} \alpha, H_{-1}{ }^{\prime} \alpha, H-14 \beta$ \\
\hline $11^{\prime}$ & & 139.71 & & & \\
\hline 12 ' & & 169.76 & & & \\
\hline 13 'a & $5.55 \mathrm{~d}(3.5)$ & 119.17 & H-7' $\alpha$ & $\mathrm{C}-7^{\prime}\left(\mathcal{J}^{3}\right), \mathrm{C}-11^{\prime}\left(\mathcal{N}^{2}\right)$ & H13'b, H-6’ $\beta$ \\
\hline $13^{\prime} \mathrm{b}$ & $6.22 \mathrm{~d}(3.5)$ & & & $\mathrm{C}-12^{\prime}\left(J^{3}\right)$ & $\mathrm{H}-13$ 'a \\
\hline 14 & $1.18 \mathrm{~d}(7.0)$ & 19.05 & $H-10^{\prime} \alpha$ & $\mathrm{C}-9^{\prime}\left(J^{3}\right), \mathrm{C}-10^{\prime}\left(J^{2}\right), \mathrm{C}-1^{\prime}\left(J^{3}\right)$ & $\mathrm{H}-10 \alpha, \mathrm{H}-8^{\prime} \beta$ \\
\hline $15^{\prime}$ & $1.28 \mathrm{~s}$ & 13.64 & & $\mathrm{C}-3^{\prime}\left(J^{3}\right), \mathrm{C}-5^{\prime}\left(J^{3}\right)$ & $\mathrm{H}-3^{\prime} \beta$ \\
\hline
\end{tabular}


methylenes, and four additional $\mathrm{sp}^{3}$ methines. Therefore, 2 should be octacyclic, and could be an adduct derived from two sesquiterpene lactones.

Partial structure of compound $\mathbf{2}$ was directly derived by comparing its spectroscopic data with those of $\mathbf{1}$, where the major changes were the ${ }^{1} \mathrm{H}$ and ${ }^{13} \mathrm{C}$ NMR signals for $\mathrm{C}(11)$ and $\mathrm{C}(13)$ which were found at higher field, connecting with the other sesquiterpene fragment. The ${ }^{1} \mathrm{H}$ NMR spectrum of the second sesquiterpene fragment of $\mathbf{2}$ displayed the two characteristic doublets (H-13'a and $\mathrm{H}-13$ 'b) of an $\alpha, \beta$-unsaturated $\gamma$-lactone $\left(\delta_{\mathrm{H}} 5.55\right.$ and $\left.6.22, \delta_{\mathrm{C}} 119.17\right)$ and their coupling constants $(J>3 \mathrm{~Hz})$ indicated a trans fusion [25] (this second sesquiterpene fragment will be described using primes (') for numbering). COSY interactions indicated that these signals were coupled with an allylic hydrogen $\left(\mathrm{H}-7^{\prime}, \delta_{\mathrm{H}} 2.59 ; \delta_{\mathrm{C}}\right.$ 47.72) vicinal to a methylene (H-6' $\alpha$ and $H-6$ ' $\beta, \delta_{H} 2.81$ and 1.72 , respectively) and to the lactonic oxymethine $\mathrm{H}-8^{\prime} \beta\left(\delta_{\mathrm{H}}\right.$ $\left.4.21, \delta_{\mathrm{C}} 80.72\right)$. This last signal was coupled vicinally with an additional methylene assigned to $\mathrm{H}^{\prime} 9^{\prime} \alpha$ and $\mathrm{H}-9^{\prime} \beta\left(\delta_{\mathrm{H}} 1.97\right.$, 2.23, respectively) and displayed $\mathrm{HMBC}$ crosspeak with the methine carbon $\left(\mathrm{C}\left(10^{\prime}\right), \delta_{\mathrm{C}} 32.68\right)$, which in turn was linked to a methyl group $\left(\mathrm{C}\left(14^{\prime}\right), \delta_{\mathrm{H}} 1.18 ; \delta_{\mathrm{C}} 19.05\right) .{ }^{2} J$ and ${ }^{3} J \mathrm{HMBC}$ crosspeaks between $\mathrm{H}-6$ ' $\alpha$ and $\mathrm{C}-5^{\prime}$ ' and $\mathrm{C}-1$ ' and between $\mathrm{H}$ 9' $\alpha$ and C-1' revealed the location of the tetrasubstituted olefin on $\mathrm{C}\left(1^{\prime}\right)$ and $\mathrm{C}\left(5^{\prime}\right)$, indicating the presence of a cycloheptene fragment. HMBC interactions between the methylene hydrogens at $\mathrm{C}-13$ and the $\mathrm{C}-1$ ' (olefinic quaternary carbon), C-2' (aliphatic methine) and C-3' (aliphatic methylene) $\left(\delta_{\mathrm{C}} 151.22\right.$,
48.36, and 52.18, respectively) and the observed NOESY cosspeaks (Fig. 2) between H-2' and H-10' and between $15^{\prime} \mathrm{CH}_{3}$ and $\mathrm{H}-3^{\prime} \beta$ (pro $S$ ) suggested that the $15^{\prime} \mathrm{CH}_{3}$ - was located at $\mathrm{C}\left(4^{\prime}\right)$ and this was confirmed by the HMBC crosspeak between $15^{\prime} \mathrm{CH}_{3}$ - and $\mathrm{C}\left(5^{\prime}\right)$, giving evidence of the presence of a bicycle [2.2.1] heptene derived from the Diels Alder addition of $\mathrm{C}\left(2^{\prime}\right)-\mathrm{C}\left(1^{\prime}\right)-\mathrm{C}\left(5^{\prime}\right)-\mathrm{C}\left(4^{\prime}\right)$ diene of a (hypothetical) guaia-1(2),4(5)-dienolide [26] and the C(11)-C(13) double bond of 11,13-dehydroeriolin (1) as dienophile, establishing the $\mathrm{C}(11)-\mathrm{C}\left(4^{\prime}\right)$ and $\mathrm{C}(13)-\mathrm{C}\left(2^{\prime}\right)$ connectivities for 2 . Having determined the regiochemistry of the Diels Alder adduct, four stereoisomers are possible from the endo (dienophile- $\alpha$, diene$\beta$ oriented (A) and dienophile- $\beta$, diene- $\alpha$ oriented (B)) and exo (dienophile- $\alpha$, diene- $\beta$ oriented $(C)$ and dienophile- $\beta$, diene $\alpha$-oriented (D)) stereorientations of the $[\pi 4 s+\pi 2 s]$ cycloaddition (See figure 1).

Analysis of the NOESY spectrum of 2 allowed to determine the conformation of the fragments and the configurations of various chiral centers (Fig. 2). The observed crosspeaks between $\mathrm{C}-14$ methyl protons with $\mathrm{C}-15$ hydrogens, between C-15 methyl protons with $\mathrm{H}-8$, and between $\mathrm{H}-5$ with $\mathrm{H}-1$ and $\mathrm{H}-7$, established the crown conformation $\left[{ }^{15} \mathrm{D}_{5},{ }_{1} \mathrm{D}^{14}\right]$ for the 11,13 -dehydroeriolin (1) fragment of 2 . In addition, the crosspeaks between $\mathrm{C}-15$ ' methyl protons and $\mathrm{H}-3$ ' pro $S$, between H-3' pro $R$ with H-2', between $\mathrm{H}-2$ ' and $\mathrm{H}-10$ ', and between C-14' methyl protons and $\mathrm{H}-8$ ' confirmed the stereochemistry at C-4', C-2', C-10' and C-8' of 2 as 4' $S, 2$ ' $S, 10^{\prime} S$ and $8^{\prime} ' S$, respectively. The transannular NOESY correlation between
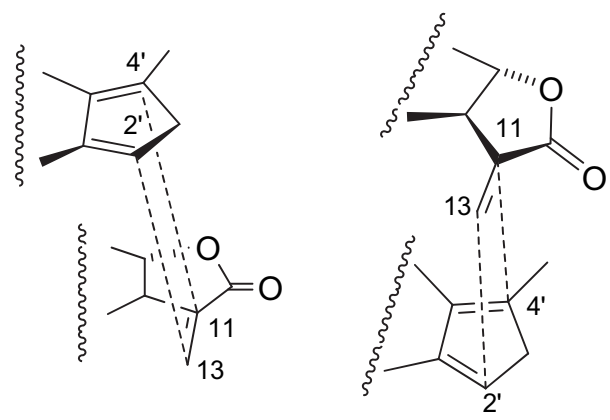

dienophile- $\alpha$, diene- $\beta$ $11\left(4^{\prime}\right), 13\left(2^{\prime}\right)$-exo

dienophile- $\beta$, diene- $\alpha$ 11(4'),13(2')-endo

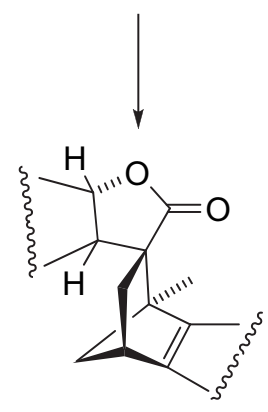

(B)

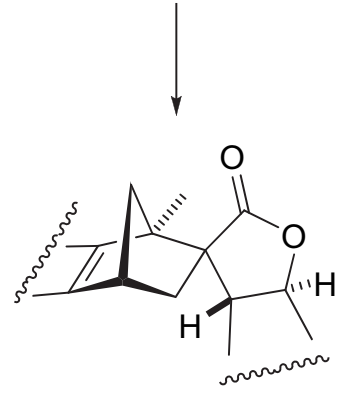

(C) $11\left(4^{\prime}\right), 13\left(2^{\prime}\right)$-exo

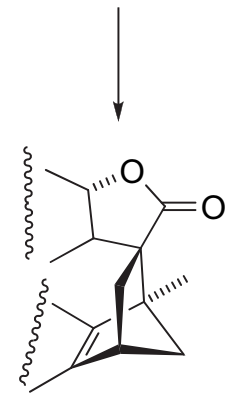

(D)

Fig. 1. Four possible stereoisomers derived from the endo ((A) and (B)) and exo ((C) and (D)) stereorientations of the $[\pi 4 \mathrm{~s}+\pi 2 \mathrm{~s}]$ cycloaddition to form 2 . 


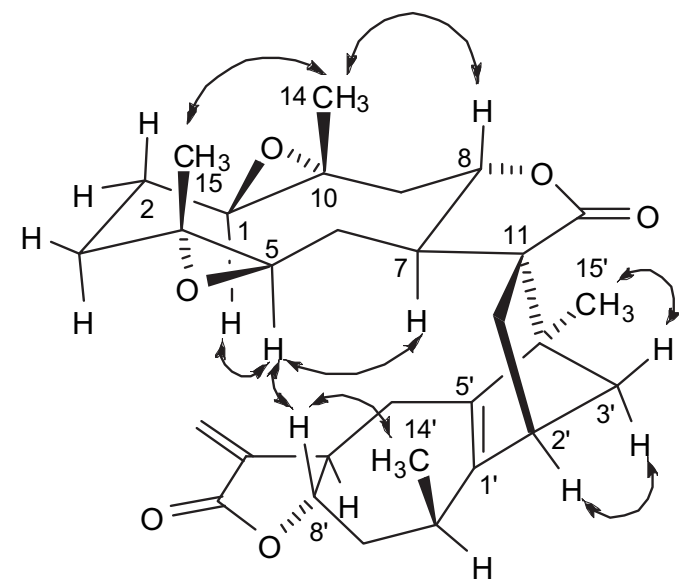

Fig. 2. Selected NOESY interactions of dischkuhriolin (2).

H-5 and H-8' was only possible considering a stacked arrangement of the sesquiterpene fragments [27] derived from the exo approach (C and D, Fig. 1), and in particular, the approach derived from the diene- $\alpha$ and the dienophile- $\beta$, as depicted for the D fragment in figure 1, established structure 2, which we have named trivially dischkuhriolin. X-ray analysis of compound $\mathbf{2}$ confirmed the structure and conformation for this novel secondary metabolite (Fig. 3) [28].

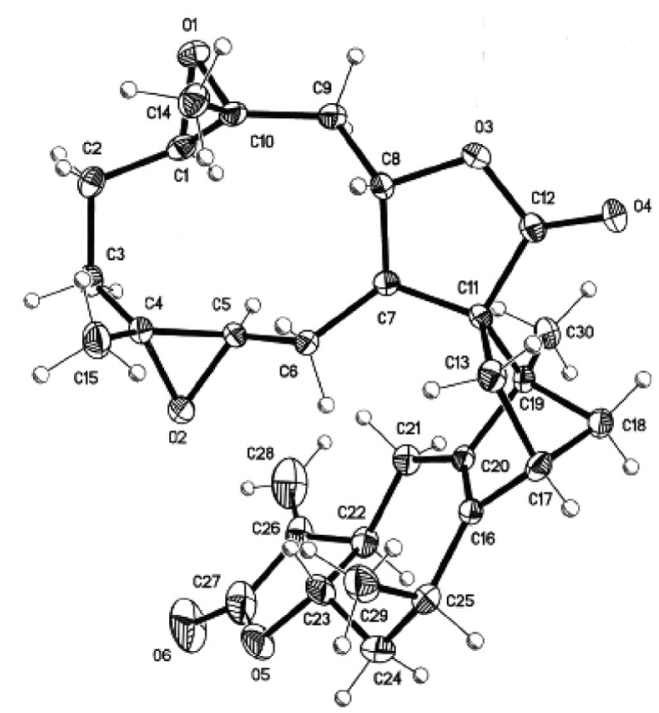

Fig. 3. ORTEP view of the X-ray diffraction structure of dischkuhriolin (2).

Silica gel chromatography of the extract of $S$. pinnata var. wislizeni followed by successive chromatographic steps on silica gel afforded compound $\mathbf{5}$ as an oil that was relatively unstable. IR (absorptions at 3492, 1763 and $1662 \mathrm{~cm}^{-1}$ ) and ${ }^{1} \mathrm{H}$ NMR $\left(\delta_{\mathrm{H}} 6.31 \mathrm{dd}, J=2.0,0.6 \mathrm{~Hz}, \mathrm{H}-13 \mathrm{a} ; \delta_{\mathrm{H}} 5.98 \mathrm{dd}, J=1.7\right.$, $0.9 \mathrm{~Hz}, \mathrm{H}-13 \mathrm{~b})$ spectra showed signals that were indicative of a sesquiterpene lactone. Acetylation of the natural prod- uct afforded compound 6 which displayed ${ }^{1} \mathrm{H}$ and ${ }^{13} \mathrm{C}$ NMR data similar with those of $\mathbf{5}$. The major difference was that $\mathbf{6}$ showed additional signals expected for the additional acetyl group and the downfield shift for H-6 $\left(\delta_{\mathrm{H}} 5.41\right.$ in $7, \delta_{\mathrm{H}} 3.87$ in $5)$. The presence of a cis- fused $\alpha, \beta$-unsaturated- $\gamma$-lactone moiety was determined by the Samek's rule correlating the value of the 7,13 allylic coupling constant $(J<3 \mathrm{~Hz})$ [25].

The structure and stereochemistry of the diacetyl derivative 6 was confirmed by the NOESY experiment in which H-7 showed strong correlation with H-5 and H-8. Complementary, H-6 showed correlation with the hydrogens H-14, establishing the chair conformation of the cyclohexane ring (Fig. 4), in agreement with $\gamma$-lactone of the A-type [25]. Therefore, the structure for the natural constituent 5 was verified as the 14-Oacetyl derivative of schkuhridin B (7) [29].

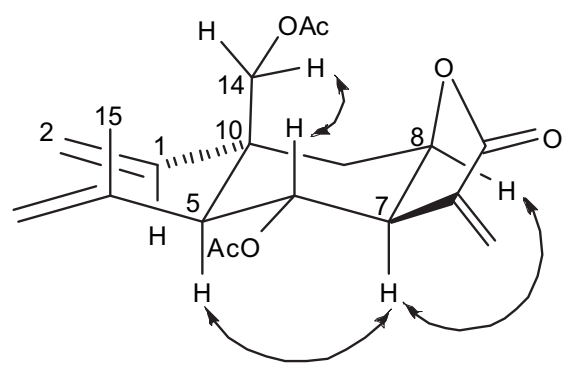

Fig. 4. Selected NOESY interactions of diacetyl schkuhridin B (6).

The ${ }^{1} \mathrm{H}$ NMR data of 5 (see experimental) and 7 [29] were practically identical to those previously published for an acetyl elemanolide (8) and its desacetyl analogous (9) isolated from the species identified as $S$. anthemoidea var. wislizeni [24], indicating that these should be the same substances. However, the reported structures of elemanolides with a trans fused lactone closed at C- 6 and an $\alpha$-oriented hydroxyl at $\mathrm{C}(8)$ were not consistent with the spectroscopic analysis, particularly with the Samek's rule [25] and with the observed NOESY correlations (fig. 4), and therefore, the structures 8 and 9 isolated from this species [30] should be modified to 5 and 7 , respectively.

The mixture of compounds $\mathbf{1 0}$ and $\mathbf{1 1}$ was obtained as an oil that showed UV absorptions for the phenolic function ( $\lambda_{\max } 228$ and $272 \mathrm{~nm}$ ) [31] and the IR indicated the existence of hydroxyl $\left(3411 \mathrm{~cm}^{-1}\right)$ and ester $\left(1738 \mathrm{~cm}^{-1}\right)$ functionalities. The mass spectra established their isomeric molecular formulas as $\mathrm{C}_{17} \mathrm{H}_{24} \mathrm{O}_{6}$ and the molecular ion showed the loss of a fragment $\mathrm{C}_{5} \mathrm{H}_{8} \mathrm{O}(\mathrm{m} / \mathrm{z} 240)$ and then the loss of a molecule of acetic acid $(\mathrm{m} / \mathrm{z} 180)$. The $2: 1$ ratio of the mixture $\mathbf{1 0}+\mathbf{1 1}$ was established by the integration of the signal that appeared in the ${ }^{1} \mathrm{H}$ NMR spectrum at $\delta_{\mathrm{H}} 3.78$ (for the major constituent) and at $\delta_{\mathrm{H}} 3.87$ (for the minor constituent). This spectrum also showed two AB-systems of the benzene ring at $\delta_{\mathrm{H}} 6.45(\mathrm{~d}, J=1.5 \mathrm{~Hz})$ and $\delta_{\mathrm{H}} 6.35(\mathrm{~d}, J=1.5 \mathrm{~Hz})$ for the major constituent and at $\delta_{\mathrm{H}}$ $6.57(\mathrm{~d}, J=1.5 \mathrm{~Hz})$ and $\delta_{\mathrm{H}} 6.49(\mathrm{~d}, J=1.5 \mathrm{~Hz})$ for the minor constituent, indicating the meta relationship for the benzenoid 
Table 2. ${ }^{1} \mathrm{H}$ and ${ }^{13} \mathrm{C}$ NMR spectral data of $6\left({ }^{\mathrm{a}} \mathrm{CDCl}_{3}, 300 \mathrm{MHz} ;{ }^{\mathrm{b}} \mathrm{CDCl}_{3}, 75 \mathrm{MHz}\right)$

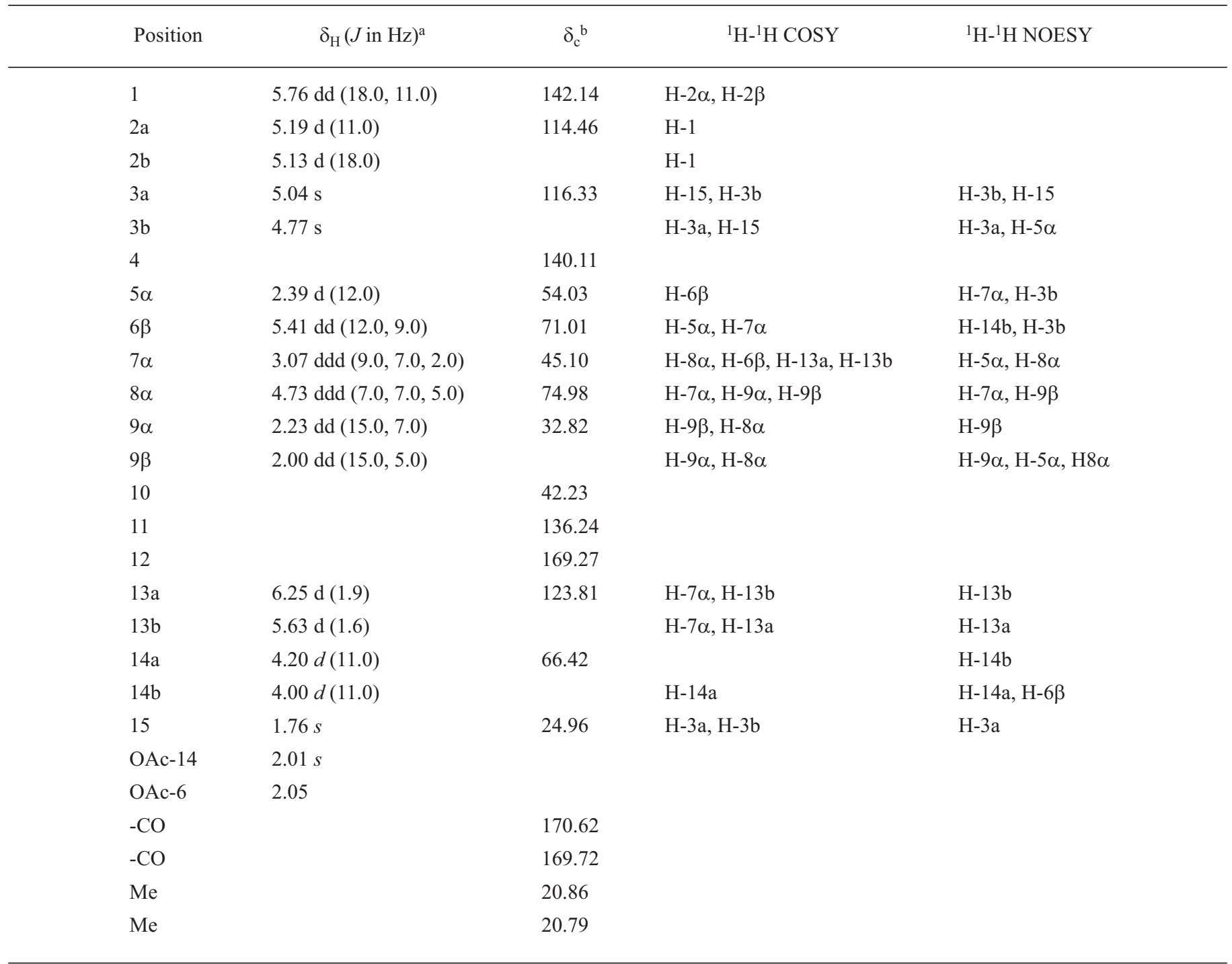

hydrogens. The phenyl propanoid fragment was confirmed by the presence of three vicinal methylenes evidenced by the COSY experiment and the chemical shift of the H-1 hydrogens $\left(\delta_{\mathrm{H}} 4.10\right.$ for $\mathbf{1 0}$ and $\delta_{\mathrm{H}} 4.09$ for 11) indicated that the acetoxy was located at $\mathrm{C}-1$.

Close comparison of the ${ }^{1} \mathrm{H}$ and ${ }^{13} \mathrm{C}$ NMR spectral data of $\mathbf{1 0}+\mathbf{1 1}$ with those reported for compounds $\mathbf{1 2}$ and $\mathbf{1 3}$ (isolated from Schkuhria schkuhrioides [15]) and their acetyl derivatives 14 and 15 (Table 3 ) revealed that they possessed the same substitution pattern, including the $\alpha$-methyl-butyryl moiety, in agreement with the molecular formula.

The vicinity of the methoxyl group and the ester for the major constituent (10) was evident by the slight up-field shift of the chemical shift for the methoxy group $\left(\delta_{\mathrm{H}} 3.78\right)$ with respect to that of the methoxy group of the minor constituent, $11\left(\delta_{\mathrm{H}} 3.87\right)$, as previously established [32]. This substitution pattern was in agreement with the observed downfield shift for H-5 and H-9 $\left(\delta_{\mathrm{H}} 6.57\right.$ and $\left.\delta_{\mathrm{H}} 6.49\right)$ for the minor constituent (11) with the ester located at C-6, in comparison with the chemical shifts of the same hydrogents for $\mathbf{1 0}$, located at $\delta_{\mathrm{H}}$ 6.35 and $\delta_{\mathrm{H}} 6.45$, respectively. ${ }^{13} \mathrm{C}$ NMR resonances (see experimental), were in agreement with the structures of the acyl phenyl propanoids $\mathbf{1 0}$ and $\mathbf{1 1}$.

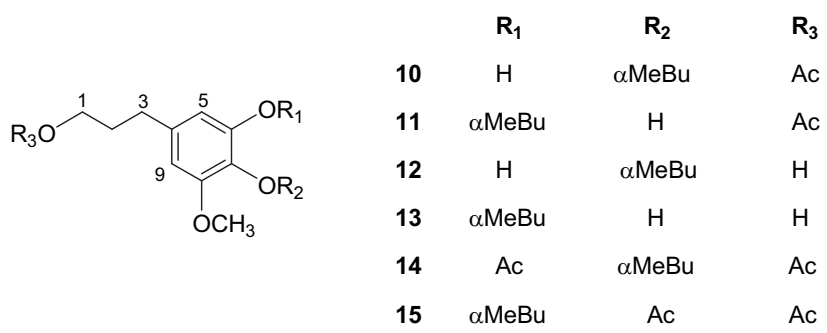


Table 3. ${ }^{1} \mathrm{H}$ NMR Data $\left(\mathrm{CDCl}_{3}, 300 \mathrm{MHz}\right)$ of compounds 10-15

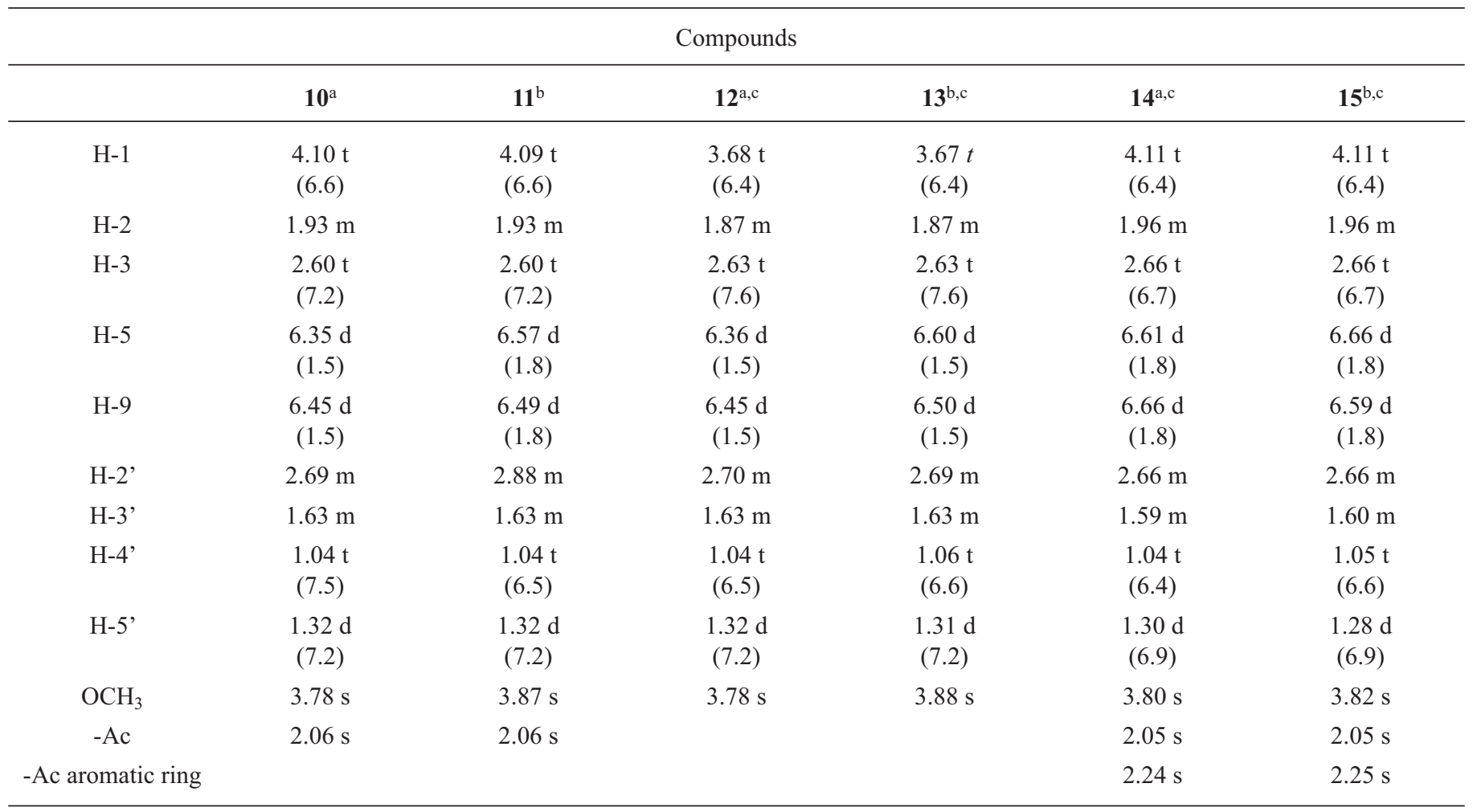

${ }^{a}$ major compound ${ }^{b}$ minor compound ${ }^{c}$ Data taken from reference [15] included here for comparison

Many plants used traditionally for medicinal purposes and natural products have been investigated searching antioxidative agents that could reduce oxidative stress, which is considered as a causative factor of many diseases [33, 34]. Therefore, the antioxidant potential of compounds $\mathbf{1}, \mathbf{2}, \mathbf{5}$ and the mixture $\mathbf{1 0}+\mathbf{1 1}$ were evaluated measuring the protective effect against 2,2-azo-bis(2-amidinopropane)dihydro chloride (AAPH)-induced damage in rat pancreatic homogenate. The bioassays were performed according standard protocols $[35,36]$ and the measurements were obtained as percentage of inhibition of peroxidation of pancreatic lipids induced by AAPH at 1, 10 and $100 \mathrm{ppm}$ of the tested substances. The results indicated that the sesquiterpene lactones 1, 2 and $\mathbf{5}$ practically did not display antioxidant activity (less than $20 \%$ of inhibition at $100 \mathrm{ppm}$ ), while the mixture of phenyl propanoids $(\mathbf{1 0}+\mathbf{1 1})$ displayed $82.50 \%$ (std. dev. 1.76 ), $76.60 \%$ (std. dev. 1.83) and $23.33 \%$ (std. dev. 2.80) of inhibition at 100, 10 and $1 \mathrm{ppm}$, respectively. These results clearly identified the acyl phenyl propanoids as protective agents against the peroxidation of lipids, and this property could be related to some of the traditional medicinal uses of this species.

The results on the chemistry of $S$. pinnata var. wisli$z e n i$ indicated the presence of secondary metabolites of different type, reflecting chemically the polymorfism of this species.

\section{Experimental}

General. Melting points were measured on a Fisher Johns apparatus and are uncorrected. Infrared spectra were recorded with FTIR Bruker TENSOR 27 instrument. Ultraviolet spectra were determined on a SHIMADZU UV160U Instrument. EIMS and HRMS $\left(\mathrm{FAB}^{+}\right)$were recorded on a JEOL SX102A mass spectrometer. The ${ }^{1} \mathrm{H}$ - and ${ }^{13} \mathrm{C}$ - NMR experiments were performed at $25{ }^{\circ} \mathrm{C}$ using Varian UnityPlus 500 spectrometer (at $500 / 125 \mathrm{MHz}$ ) and Varian VXR-300 (at 300/75 MHz), and the chemical shifts are expressed in parts per million $(\delta)$ relative to trimethylsilane. Column chromatographies (CC) were carried out on silica gel (70-230, 230-400 mesh and TLC grade). Thin layer chromatography analyses were made on aluminum silica gel $60 \mathrm{~F}_{254}$ (Alugram SiG/UV $\mathrm{UV}_{254}$, Macherey-Nagel) plates and visualization was accomplished with either a UV lamp or a solution of ammonium cerium sulfate.

Plant material. Aerial parts of Schkuhria pinnata (Lam.) Kuntze var. wislizeni (A. Gray) B. L. Turner were collected 2 $\mathrm{km}$ North of the city of León on road to Aguascalientes, state of Guanajuato, Mexico, in September, 2001. The identification was confirmed by Dr. José Luis Villaseñor (Instituto de Biología de la Universidad Nacional Autónoma de México) and a voucher specimen (Registry number 1113905) was deposited at the National Herbarium, Instituto de Biología, UNAM. 
Extraction and isolation. The dried aerial parts of $S$. pinnata $(8 \mathrm{~kg})$ were extracted two times with $n$-hexane and then with acetone at room temperature. The acetonic extract $(200 \mathrm{~g})$ was subjected to VCC [37] over $1 \mathrm{~kg}$ silica gel (230-400 mesh), using $n$-hexane/EtOAc as eluent, $400 \mathrm{~mL}$ fractions were collected. Fractions eluted were combined to afford fractions A-S. Frs. A-C (15.5 g) yielded unsaturated fatty acids. Frs. I-J (3.9 g) were joined and chromatographed by $\mathrm{CC}\left(\mathrm{SiO}_{2}\right.$, gradient $n$-hexane/Acetone) to obtain 12 fractions (IJ.1-IJ.12). Fr. IJ.9 $\left(490 \mathrm{mg}\right.$ ) was purified over silica gel using $\mathrm{CH}_{2} \mathrm{Cl}_{2} /$ Acetone as eluent to afford 65 fractions (IJ.9.1-IJ.9.65). Frs. IJ.9.30-IJ.9.45 $(117 \mathrm{mg})$ were subjected to preparative TLC using $n$-hexane/EtOAc $(7: 3)$ as eluent to give the mixture of 1-O-acetyl-3[6-hydroxy, 8-methoxy, 7-(2'-methyl-butyryloxy)]-phenyl-1-propanol (10) + 1-O-acetyl-3[7-hydroxy, 8-methoxy, 6-(2'-methyl-butyryloxy)]-phenyl-1-propanol (11) (52 mg, $0.65 \%$ of dry weight) as yellow oil: $\mathrm{UV}\left(\mathrm{CH}_{2} \mathrm{Cl}_{2}\right) \lambda_{\max }$ $(\log \varepsilon): 228$ (3.32), $272(3.17) \mathrm{nm}$; IR $v_{\max }\left(\mathrm{CHCl}_{3}\right): 3411$, 2969, 2939, 2878, 1738, 1604, 1515, 1461, 1433, 1366, 1242, $1174,1107,1041,896,825,756 \mathrm{~cm}^{-1} ;{ }^{1} \mathrm{H}$ NMR $\left(\mathrm{CDCl}_{3}, 300\right.$ $\mathrm{MHz}$, see table $3 .{ }^{13} \mathrm{C} \mathrm{NMR}\left(\mathrm{CDCl}_{3}, 75 \mathrm{MHz}\right) \delta 174.60(-$ $\mathrm{CO}), 174.43$ (-CO), $171.18(-\mathrm{CO} \times 2), 151.72,148.12,147.58$, $139.85,137.63,132.39,125.92(-\mathrm{C}=\mathrm{Ar}), 115.00,109.14$, $108.5,104.55,104.59(-\mathrm{CH}=\mathrm{Ar}), 63.79\left(-\mathrm{CH}_{2}-\mathrm{O}\right), 56.28$, $55.98\left(-\mathrm{OCH}_{3}\right), 41.02\left(\mathrm{C}-2^{\prime} \times 2\right), 34.00,33.34,31.86,30.22$, 29.96, 26.84, $\left(-\mathrm{CH}_{2}\right), 20.96,19.08,16.75,11.45\left(-\mathrm{CH}_{3}\right)$; EIMS $\mathrm{m} / z$ (rel. int.): $324[\mathrm{M}]^{+}(11), 310$ (11), 240 (100), 198 (8), 180 (64), 179 (10), 153 (16), 152 (8), 123 (5), 119 (4), 91 (5), 85 (16), 71 (17), 57 (55), 43 (29), 41 (9). Frs. IJ.9.47-IJ.9.62 were joined and purified by preparative TLC using $\mathrm{CH}_{2} \mathrm{Cl}_{2} / \mathrm{MeOH}$ (95:5) as the developing solvent afforded $p$-hydroxy-benzaldehyde [23] (1.6 mg, $0.02 \%$ of dry weight). Frs K-L (7.2 g) afforded pectolarigenin (3 [21], $81.8 \mathrm{mg}, 1.02 \%$ of dry weight) which was recristalized from $n$-hexane/MeOH. Fr. M $(21.9 \mathrm{~g})$ was chromatographed over $\mathrm{SiO}_{2}$ (gradient, $\mathrm{CH}_{2} \mathrm{Cl}_{2}$ /Acetone) to obtain 74 fractions (M.1-M.74). Frs. M.15-M.38 (1.8 g) were combined and the residue was subjected to $\mathrm{CC}\left(\mathrm{SiO}_{2}\right.$, gradient, $\left.\mathrm{CH}_{2} \mathrm{Cl}_{2} / \mathrm{MeOH}\right)$ giving 86 fractions, from the frs. 77-79 was obtained 14-O-acetyl schkuhridin B (5 [28], $12 \mathrm{mg}$, $0.15 \%$ of dry weight $)$ as colorless oil: IR $\left(\mathrm{CHCl}_{3}\right) v_{\max }: 3492$, 3080, 2967, 2934, 1763, 1662, 1640, 1439, 1382, 1337, 1266, 1241, 1151, 1129, 1083, 1041, 1002, 950, 922, 894, 816, 785, $759,726 \mathrm{~cm}^{-1} .{ }^{1} \mathrm{H}$ NMR $\left(\mathrm{CDCl}_{3}, 300 \mathrm{MHz}\right.$ assignments by COSY, HETCOR and NOESY): $5.77(1 \mathrm{H}, \mathrm{dd}, J=18,11, \mathrm{H}-$ 1), $5.18(1 \mathrm{H}, \mathrm{d}, J=11, \mathrm{H}-2 \mathrm{a}), 5.12(1 \mathrm{H}, \mathrm{d}, J=18, \mathrm{H}-2 \mathrm{~b}), 5.22$ $(1 \mathrm{H}$, br s, H-3a), $4.85(1 \mathrm{H}$, br s, H-3b), $2.21(1 \mathrm{H}, \mathrm{d}, J=12$, $\mathrm{H}-5), 3.87$ (1H, dd, $J=12,9, \mathrm{H}-6), 2.94$ (1H, dddd, $J=9,7$, 2, 1.7, H-7), 4.75 (1H, ddd, $J=7,7,5, \mathrm{H}-8), 2.15(1 \mathrm{H}, \mathrm{dd}, J=$ $15,7, \mathrm{H}-9 \alpha), 1.93(1 \mathrm{H}, \mathrm{dd}, J=15,5, \mathrm{H}-9 \beta), 6.31(1 \mathrm{H}, \mathrm{dd}, J=$ 2, 0.6, H-13a), 5.98 (1H, dd, $J=1.7,0.9, \mathrm{H}-13 \mathrm{~b}), 4.14(1 \mathrm{H}, \mathrm{d}$, $J=11, \mathrm{H}-14 \mathrm{a}), 3.95$ (1H, d, $J=11, \mathrm{H}-14 \mathrm{~b}), 1.84$ (3H, s, H-15), $2.02(3 \mathrm{H}, \mathrm{s},-\mathrm{OAc})$. These data are practically identical to those reported in ref. [24]. Fraction N (29.1 g) was purified by CC $\left(\mathrm{SiO}_{2}\right.$, gradient, $n$-hexane/EtOAc) to give 11,13 -dehydroeriolin $(1$ [19,20], $768 \mathrm{mg}, 9.6 \%$ of dry weight) and rechromatography of the more polar fractions $\left(\mathrm{SiO}_{2}\right.$, elution with $n$-hex-
ane/EtOAc) afforded hispidulin (4 [22], $70 \mathrm{mg}, 0.87 \%$ of dry weight). Fraction $\mathrm{O}(5.19 \mathrm{~g})$ was subjected to $\mathrm{CC}$ over silica gel using $n$-hexane/EtOAc as eluent to yield dischkuhriolin (2, $16.8 \mathrm{mg}, 0.21 \%$ of dry weight) as white needles crystals: $\mathrm{mp}$ $220-223{ }^{\circ} \mathrm{C},[\alpha]_{\mathrm{D}}{ }^{25}-78.18$ (c 0. 11, $\left.\mathrm{CHCl}_{3}\right) ; \mathrm{UV}\left(\mathrm{CH}_{2} \mathrm{Cl}_{2}\right) \lambda_{\max }$ $\mathrm{nm}(\log \varepsilon) 230.5$ (3.21); IR $\left(\mathrm{CHCl}_{3}\right) v_{\max } 3693,2969,2940$, 2878, 1761, 1603, 1463, 1388, 1331, 1308, 1150, 1094, 1061, 1026, 986, 943, $914 \mathrm{~cm}^{-1} .{ }^{1} \mathrm{H}$ NMR $\left(\mathrm{CDCl}_{3}, 500 \mathrm{MHz}\right)$ and ${ }^{13} \mathrm{C}$ NMR $\left(\mathrm{CDCl}_{3}, 125 \mathrm{MHz}\right)$ (assignments by COSY, HSQC, HMBC and NOESY), are shown in table 1 . EIMS $m / z$ (rel. int.): $494[\mathrm{M}]^{+}$(29), 460 (5), 443 (2), 391 (2), 335 (5), 307 (36), 289 (17), 273 (3), 245 (4), 230 (2), 154 (100), 136 (75), 107 (20), 89 (18), 77 (15), 55 (9), 39 (7). HRMS (FAB $\left.{ }^{+}\right) \mathrm{m} / z$ : Calcd. for $\mathrm{C}_{30} \mathrm{H}_{38} \mathrm{O}_{6}+\mathrm{H}^{+}$: 495.2747; found 495.2750.

Acetylation of 14-O-acetyl schkuhridin B (5). From fraction $M$ obtained from the initial chromatographic procedure, frs. M.39-M.55 were combined and the residue $(312 \mathrm{mg})$ was dissolved in pyridine $(1.5 \mathrm{~mL})$ and acetic anhydride $(2 \mathrm{~mL})$. The mixture was stirred for $26 \mathrm{~h}$ at room temperature and the reaction was monitored by TLC. When the reaction was completed, ice $(6 \mathrm{~g})$ was added and stirred for $1 \mathrm{~h}$, then the reaction mixture was extracted with $\mathrm{CH}_{2} \mathrm{Cl}_{2}(3 \times 15 \mathrm{~mL})$, the organic layers were joined and washed with $\mathrm{HCl}(10 \%, 2 \times 15 \mathrm{~mL})$, with a solution of sat. $\mathrm{NaHCO}_{3}(2 \times 15 \mathrm{~mL})$, and with brine, dried over $\mathrm{Na}_{2} \mathrm{SO}_{4}$ and concentrated under vacuum. Usual workup afforded a yellow oil $(241 \mathrm{mg})$ which was purified by column chromatography using $n$-hexane/EtOAc affording some fractions which were further purified by preparative TLC (using $n$ hexane/Acetone 4:1 as developing solvent, two developments), to afford diacetyl schkuhridin B (6,25.4 mg) as a colorless oil: $[\alpha]_{\mathrm{D}}^{25}+109.6\left(c\right.$ 0.12, $\left.\mathrm{CHCl}_{3}\right)$; UV $\left(\mathrm{CHCl}_{3}\right) \lambda_{\max }(\log \varepsilon) 243$ (2.64) nm; IR $\left(\mathrm{CHCl}_{3}\right) v_{\max } 3518,3086,2970,2930,1907$, $1768,1742,1666,1642,1452,1414,1374,1155,1035,954$, $922 \mathrm{~cm}^{-1} ;{ }^{1} \mathrm{H} \mathrm{NMR}\left(\mathrm{CDCl}_{3} 300 \mathrm{MHz}\right)$ and ${ }^{13} \mathrm{C} \mathrm{NMR}\left(\mathrm{CDCl}_{3}\right.$, $75 \mathrm{MHz}$ ) (assignments by COSY, HETCOR and NOESY): data shown in table 2; EIMS $m / z$ (rel. int.) $348[\mathrm{M}]^{+}(0.9), 306(14)$, 289(3), 276(1), 262(1), 246(13), 228(36), 216(8), 200(13), 183(12), 171(13), 157(10), 143(15), 131(13), 117(11), 105(17), 91(23), 79(12), 77(8), 43(100), 41(11), 18(3), 15(2).

Antioxidant activity assay. Male Wistar rats (200-250 g weight) were obtained from Instituto de Fisiología Celular de la Universidad Nacional Autónoma de México, and treated following the procedures of the NIH publication 85-23 "Principles of Laboratory Animal Care" and the Norma Oficial Mexicana NOM-062-ZOO-1993. The antioxidant activity was measured in a rat pancreas homogenate and the degree of lipid peroxidation was determined according previous protocols [35, 36, 38].

\section{Acknowledgements}

This work was supported by Universidad Nacional Autónoma de México and Consejo Nacional de Ciencia y Tecnología (Scholarships to A.L. and B.M.R.). The assistance of Ma. 
Teresa Ramírez Apan, Rocío Patiño, Beatriz Quiroz, José M. Narváez-Mastache, Antonio Nieto, Héctor Ríos, Luis Velasco, Javier Pérez Flores and José Luis Villaseñor is gratefully acknowledged.

\section{References}

1. Heiser, Ch. B. Ann. Miss. Bot. Gar. 1945, 32, 265-277.

2. Rydberg, P. A. North American Flora 1914, 34, 44-47.

3. McVaugh, R. Fl. Novo-Galiciana 1984, 12, 794-799.

4. Turner, B. L. Phytologia 1995, 79, 364-368.

5. http://www.ars-grin.gov/cgi-bin/npgs/html/taxon.pl?413435.

6. Martínez, M. Las Plantas Medicinales de México, Ed. Botas. 1954.

7. Bascope, M.; Sterner, O. Rev. Bol. Quím. 2007, 24, 14-25. von Koenen, E. Medicinal, Poisonous, and Edible Plants in Namibia. Klaus Hess Publishers. Verlag. 2001. Deutschländer, M.S.; van de Venter, M.; Roux, J.L.; Lall, N. J. Ethnopharmacol. 2009, 124, 619-624. Muthaura, C.N.; Rukunga, G.M.; Chhabra, S.C.; Omar, S.A.; Guantai, A.N.; Gathirwa, J.W.; Tolo, F.M.; Mwitari, P.G.; Keter, L.K.; Kirira, P.G.; Kimani, C.W.; Mungai, G.M.; Njagi, E.N.M. Phytotherapy Research 2007, 21, 860-867.

8. Luseba, D.; Elgorashi, E. E.; Ntloedibe, D. T.; Van Staden, J. South Afr. J. Bot. 2007, 73, 378-383.

9. Bohlmann, F.; Zdero, Ch. Phytochemistry 1977, 16, 780-781.

10. Bohlmann, F.; Jakupovic, J.; Robinson, H.; King, R. Phytochemistry 1980, 19, 881-884.

11. Herz, W.; Govindan, S. Phytochemistry 1980, 19, 1234-1236.

12. Pettei, M. J.; Miura, Y.; Kubo, Y.; Nakanishi, K. Heterocycles 1978, 11, 471-480.

13. Delgado, G.; Hernández, H.; Romo de Vivar, A. J. Org. Chem. 1984, 49, 2994-2996.

14. Pérez, A. L.; Mendoza, J. S.; Romo de Vivar, A. Phytochemistry 1984, 23, 2911-2913.

15. Delgado, G.; Tejeda V. Nat. Prod. Lett. 1998, 12, 17-22.

16. Delgado, G.; Tejeda, V.; Salas, A.; Chávez, M. I.; Guzmán, S.; Bolaños, A.; Aguilar, M. I.; Navarro, V.; Villarreal, M. L. J. Nat. Prod. 1998, 61, 1082-1085.

17. García, A.; Delgado, G. Helv. Chim. Acta 2006, 89, 16-29. Cano, A.; Espinoza, M.; Ramos, C. H.; Delgado, G. J. Mex. Chem. Soc. 2006, 50, 71-75.

18. Villaseñor Ríos, J. L.; Espinosa García, F. J. Catálogo de Malezas de México. Universidad Nacional Autónoma de México y Fondo de Cultura Económica. 1998. Espinosa García, F. J.; Sarukhán, J. Manual de Malezas del Valle de México. Universidad Nacional Autónoma de México y Fondo de Cultura Económica. 1997.

19. Romo de Vivar, A.; Pérez, A. L.; León, C.; Delgado, G. Phytochemistry 1982, 21, 2905-2908.

20. Calderón, J. S.; Quijano, L.; Gómez-Garibay, F.; Sánchez, D. M.; Rios, T.; Fronczek, F. R. Phytochemistry 1987, 26, 1747-1750.

21. Hase, T.; Ohtani, K.; Kasai, R.; Yamasaki, K.; Picheansoonthon, C. Phytochemistry 1995, 40, 287-290.

22. Iwashina, T.; Kamenosono, K.; Ueno, T. Phytochemistry 1999, $51,1109-1111$.

23. Woodhead, S.; Galeffi, C.; Bettolo, G. B. M. Phytochemistry 1982, 21, 455-456.

24. Stewart, E.; Mabry, T. J. Phytochemistry 1985, 24, 2731-2732.

25. Samek, Z.; Harmatha, J. Coll. Czech. Chem. Commun. 1978, 43, 2779-2799.

26. The hypothetical 1(2),4(5)-H10 $\alpha$-guaiadienolide (i) could be formed from the same intermediate that would produce 11,13dehydroeriolin (1), namely, the 4(5)-epoxy-germacrolide (ii, $4 \alpha, 5 \beta$-epoxy-8-epi-inunolide) [20]. The transannular reaction could afford the cation iii, and the stabilization of the reactive intermediate and dehydration can produce $\mathbf{i}$.

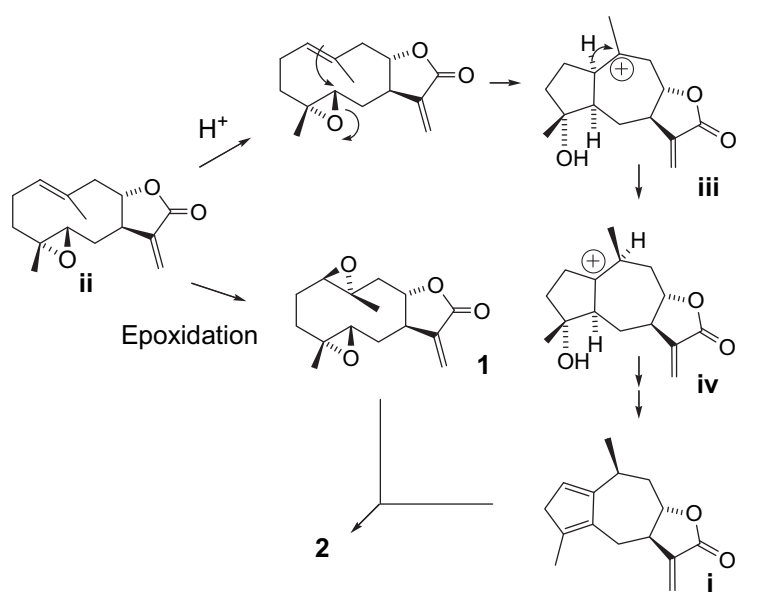

27. Fragments A and B (Fig. 1, derived from an endo approach in the Diels Alder reaction) have the sesquiterpene residues with an extended arrangement, in contrast with the exo approach (fragments $\mathrm{C}$ and D, Fig. 1) that produce stacked arrangement of the sesquiterpene fragments.

28. X-ray analysis data for compound 2. All data were collected on Brucker Smart Apex CCD diffractometer using 1.93 to $25.02 \theta$ at 293(2) K. The refinement methods was full-matrix least squares on $F^{2} . \mathrm{C}_{30} \mathrm{H}_{38} \mathrm{O}_{6} ; M=494.60$; crystal system monoclinic; space group $\mathrm{P} 21 ; a=11.162(1) \AA ; b=8.6749(5) \AA ; c=14.221(1) \AA$; $\alpha=90^{\circ} ; \beta=109.018(1)^{\circ} ; \gamma=90^{\circ} ; V=1301.8(1) \AA^{3} ; Z=2 ; D_{x}=$ $1.262 \mathrm{Mgm}^{-3} ; \mathrm{M}=0.087 \mathrm{~mm}^{-1} ; F(000)=532$; crystal size $0.418 \times$ 0.274 ' 0.100 ; colorless prism. Index ranges $-13 \leq h \leq 13,-10 \leq$ $k \leq 10,-16 \leq l \leq 16.10765$ reflections were collected and 4577 $[\mathrm{R}($ int $)=0.0558]$ reflections were independents. Completeness to $\theta=25.02^{\circ} 99.9 \%$; final $\mathrm{R}$ indices $[I>2 \sigma(I)] R 1=0.0449, w R 2=$ 0.0547 ; $R$ indices (all data) $R 1=0.0808, w R 2=0.0616$; Largest diff. peak and hole were 0.119 and -0.129 e $\AA^{-3}$. CCDC-753938 contains the supplementary crystallographic data for this paper. These data can be obtained free of charge via http://www.ccdc. cam.ac.uk/data_request/cif.

29. Delgado, G.; Guzmán, S.; Romo de Vivar, A. Phytochemistry 1987, 26, 755-759.

30. The species identified as Schkuhria anthemoidea var. wislizeni (Gray) Heiser analyzed by Mabry [24] should be considered as Schkuhria pinnata (Lam.) Kuntze var. wislizeni (A. Gray) B. L. Turner, according to Turner [4]. This is supported by the chemical constituents reported in this contribution. It is interesting to note that 11,13-dehydroeriolin (1) may be considered as a typical secondary metabolite of the species now identified as $S$. pinnata var. wislizeni. The original reports informing this substance as a constituent of Schkuhria schkuhrioides [13, 19] could be considered for further confirmation, since subsequent analyses for this last species $[15,16]$ did not afford this sesquiterpene lactone.

31. Chen, Ch.-Y.; Shen, Y.-Ch.; Chen, Y.-J-; Shen, J.-H.; Duh, CH.-Y. J. Nat. Prod. 1999, 62, 573-576.

32. Su, W.-Ch.; Fang, J.-M.; Cheng, Y.-Sh. Phytochemistry 1995, 40, 563-566.

33. Soto, C.; Recoba, R.; Barrón, H.; Álvarez, C.; Favari, L. Comp. Biochem. Physiol. 2003, 136C, 205212.

34. Quine, S. D.; Raghu, P. S. Pharmacol. Rep. 2005, 57, 610-615.

35. Narváez-Mastache, J. M.; Soto, C.; Delgado, G. Biol. Pharm. Bull. 2007, 30, 1503-1510.

36. Ohkawa, H.; Ohishi, N.; Yagi, K. Anal. Biochem. 1979, 95, 351358.

37. Coll, J. C.; Bowden, B. F. J. Nat. Prod. 1986, 49, 934-936

38. Narváez-Mastache, J. M.; Novillo, F.; Delgado, G. Phytochemistry 2008, 69, 451-456. 